\title{
The legal status of minorities and universities in inter-war Czechoslovakia
}

\author{
prof. JUDr. Jan KUKLÍK, DrSc. \\ JUDr. PhDr. René PETRÁŠ, Ph.D.
}

\begin{abstract}
Minority issues are still topical and their legal solution is complicated. Minority universities, which are an uncommon phenomenon, are a specific feature of this issue. While education in minority languages at elementary and even secondary schools is common, teaching in minority languages at the highest level of education is occurs infrequently. In the overall view of historical development, it is also necessary to recognize that colleges have traditionally been conceived as transnational, and Latin has been a common language in Europe from colleges' medieval beginnings to modern times.

In the Czech lands, however, minority universities originated in principle at the end of the monarchy. At that time, however, minority universities were those with instruction predominantly in Czech (in addition to already existing German), that is, in a language prevalent in the Czech lands, but unprivileged within the framework of the monarchy. After the rise of Czechoslovakia, higher education in German remained, although Germans constituted a real minority. As a result, higher education in German was a very exceptional issue at that time.
\end{abstract}

\section{Keywords}

legal status of minorities, minority universities, history of Czechoslovakia

\section{General issues of legal status of minorities}

The minority question and its legal solution is a complicated problem, which requires, at least, a general outline. Minorities traditionally (especially in the first half of the $20^{\text {th }}$ century) were divided into religious, racial or ethnic categories. Higher schools for a particular religious or racial group may be found, but in modern Europe it is not a common phenomenon. Thus, the question of language origin is of key importance if, as usual, minority and minority groups differ in language. The predominant language of instruction is indeed a fundamental practical element, which in the case of less widely used languages, such as Czech (except for clarity for close Slovak), Slovak (similarly to Czech) and Hungarian, which means the actual closure of such a college for the members of other nations. 
In Central Europe, especially since 1848, minorities have had a major role to play and are predominantly defined through language. A key issue of national minorities is still mainly the language used by the authorities and in national education. Of the three essential elements of the minority issue, namely the official language, minority education and the possibility of minorities to take part in resolution of the questions that concern them this classical trio is also found in the current Czech Charter of Fundamental Rights and Freedoms - two are related to language. If a language minority is sufficiently large or influential, then practice requires that this population can communicate with authorities in their own language and children can learn in that language. On the other hand, especially for financial reasons and due to the functioning of administration, one should prefer a language, and it is usually not possible for small scattered minorities to use their language. For example, the Constitution of the Czech lands, which was in effect the longest since the 1867-1918 period, introduced the official unlimited equality of nations in the state in the famous Article 19 (Ground Law No. 142/1867 of the Reich Code), but practice looked different, even in the case of the language universities with a clear preference for German. ${ }^{1}$ However, individual states are completely different from the viewpoint of the concept of the legal status of minorities, and this is almost unimaginable in most basic legal areas. Perhaps four groups can be distinguished. In the first one, apart from exceptions, there is no legal regulation of minority status for two possible generic causes. Some countries - traditionally France or the US - do not recognize the existence of minorities and the citizens are equal citizens, but they must use the state language in public life. Even children in schools can usually talk only in it. Rights for minorities would be perceived as a violation of the equality of the population. The legal orders of other states essentially ignore the existence of nationalities, such as Czechoslovakia from 1945 until 1960.

The second group has a system of a declaration where the state usually proclaims the equality of nations in the constitution, but other legislation is very limited and nonsystematic, such as Cisleithania according to Article 19 of Ground Law No. 142/1867 of the Reich Code, which apparently contributed to the chaos, or Switzerland, where, on the contrary, the minimum legal regulation traditionally works well. The third group has a detailed legal regulation where some provisions are in constitutional laws, others are contained in general laws, and there are also subordinate standards. This system was in interwar Czechoslovakia, and since the sixties it has been common in the Czech lands. As a fourth group it is noteworthy that there are many autonomous or federative formations where nationalities can take part in the making of the legal regulation. ${ }^{2}$

\footnotetext{
1 PETRÁŠ, René: Národní otázka v českých zemích na sklonku monarchie [The national question in the Czech lands at the end of the monarchy], in: Vývoj české ústavnosti v letech 1618-1918 [The development of Czech constitutionality in years 1618-1918], MALÝ, Karel - SOUKUP, Ladislav (eds.), Prague 2006, 694-740; PETRÁŠ, René: Problémy právního postavení menšin [Problems of legal status of minorities], in: Aktuální problémy právního postavení menšin v České republice [Current problems of the legal status of minorities in the Czech Republic], PETRÁŠ, René (ed.), Prague 2010, 35.
} 


\section{The legal regulation of education at the end of the monarchy and in interwar Czechoslovakia}

Another important element to be outlined is the overall legal regulation of education, including linguistic aspects, at the end of the monarchy, which was largely taken over by inter-war Czechoslovakia. The legal regulation of education at the end of the monarchy and beyond in the republic did not, however, make a major difference to the position of the dominant nation and other linguistic groups. The relatively large adjustments to the education system therefore included only some regulations dealing with the existence of different nations in the state.

School tuition - the language problem in schools - was in Cisleithania ${ }^{3}$ generally regulated by Article 19 (3) of Act No. 142/1867 R. G. BI. (Reichsgesetzblatt), further by Act No. $62 / 1869$ R. G. Bl., concerning schools of general, burgess and pedagogical education. There was no law on classical grammar schools and universities, and the matter fell under Reich law. However, real grammar schools were regulated by provincial legislation. The division of legislative competences in the field of education was therefore nothing simple. The legislation left the setting up of schools and the use of languages in them, largely to the discretion of the competent authorities. In general, during monarchy in the Czech lands were quite decent in terms of education, but negative elements were also found, including non-German universities whose creation was extremely politicized. In Hungary before 1918, Hungarian had a completely dominant position in education, and there was essentially Hungarianization, which was also supported by administrative practice. ${ }^{4}$

The new Czechoslovakia generally assumed the entire legal system from the era of monarchy, but regarding the minority issue, a completely different arrangement was quickly created. In the general regulation of education in the years 1919-1920 a number of legal acts were issued that newly regulated this area, while minority education was in the centre of interest. Legal regulation of minority issue in education was absurdly fragmented. ${ }^{5}$ There were even international obligations, contained in particular in Articles 8 and 9 of the so-called Small Agreements of St. Germain of 10 September 1919, which were incorporated into the constitutional charter (sec. 130 and sec. 131) and the (constitutional) language law (sec. 5) of 29 February 1920. According to sec. 130, citizens (within the limits of general laws) could set up, manage and administrate schools and other educational institutions, freely use their language and practice their religion. Paragraph 131 of the Constitution guaranteed that the children of citizens of a language other than the state in areas where they had a significant share of the population would obtain public teaching in their own language.

3 See especially BURGER, Hannelore: Sprachenrecht und Sprachgerechtigkeit im österreichischen Unterrichtswesen 1867-1918, Wien 1995.

4 In detail see PETRÁŠ, René: Menšiny v meziválečném Československu [Minorities in inter-war Czechoslovakia], Prague 2009, 323-324.

5 See f.e. SOBOTA, Emil: Národnostní právo československé [National Law of Czechoslovakia], Brno 1927, 44-47; PEŠKA, Zdeněk: Československá ústava a zákony s ní souvislé II [The Czechoslovak Constitution and Related Laws II], Prague 1935, 1722-1740. 
The language law in sec. 5 followed up on sec. 131 of the constitutional charter, referring to the international treaty: "Teaching in all schools for members of national minorities takes place in their language, as well as the cultural institutions established for them, are managed with this language (Article 9 of the Treaty St. Germain)."

The entitlement of children of citizens of a language other than Czechoslovak to learn in their own language was granted within the limits of general laws, i.e. the general legal regulation of teaching, because there were usually no special legal regulations. This general arrangement was mainly constituted by Act No. 62/1869 of R. G. Bl. on the establishment of schools of general, burgess and pedagogical education. After the establishment of the republic, the law was supplemented by the law of 3 April 1919 (No. 189), on schools of national and private institutes of teaching and education, which was the basic legal norm for the organization of so-called minority education. But a national minority in this law was understood to be a minority in a particular municipality and not in the whole of the republic, as would correspond to the constitutional charter and other laws. A minority for the purposes of this Act also included members of the state nation if they were a minority in the district of the school and in practice, according to this law, strong state support was created mainly for children of Czech state employees in purely German areas. The inter-war minority education in Czechoslovakia had, despite its overall quality, a number of peculiar and absurd elements. ${ }^{6}$ A major problem was the considerable reduction of autonomous elements in education compared to the monarchy. ${ }^{7}$

The language question in schools was also governed by many other regulations. These included, for example, laws and regulations established by universities, vocational schools or other types of educational institutions, where a language of instruction was also designated, e.g. Act No. 50/1919 Sb. on the establishment of the second Czech university in Brno, Act No. 197/1919 Sb. on the establishment of Hus's Evangelical Faculty of Theology, Act No. 375/1919 Sb. on the establishment of the Czechoslovak State University in Bratislava. It also included provisions on the language of examinations at universities (e.g. Government Decree No. 122/1919 Sb., No. 353/1919 Sb., No. 214/1921 Sb.), as well as provisions on the knowledge of the language of the school in the examination of teaching capacity for schools of general and bourgeois education in Slovakia (Act No. 276/1920 Sb.). The minority question was also related to regulations covering what is to be taught in schools as a foreign language: especially Act No. 73/1922 Sb., which regulates teaching in modern languages, Act No. 137/1923 Sb., on the teaching of the language of the state and of the language of national minorities at secondary schools and educational institutes. ${ }^{8}$

6 KURAL, Václav: Konflikt místo společenství? [Conflict Instead of Community?], Prague 1993, $96-101$.

7 In detail see PETRÁŠ, Menšiny..., 324-327; HORÁČEK, Cyril: Jazykové právo československé republiky [Language Law of the Czechoslovak Republic], Prague 1928, 106-107; TRAPL, Miloš: České menšinové školství v letech 1918-1938 [Czech minority education in years 1918-1938], in: České národní aktivity v pohraničních oblastech prvni Československé republiky [Czech National Activities in the Borderlands of the First Czechoslovak Republic], Olomouc - Opava 2003, 109-117.

8 See PETRÁŠ, Menšiny..., 327-328. 


\section{Specifics of higher education institutions and minorities in interwar Czechoslovakia}

In studying the issue of minority higher education institutions, it is necessary to constantly be aware of the significant specifics of this level of education, in terms of the system of higher education. Since the $19^{\text {th }}$ century, Charles University was not the only university, as it had been in the Middle Ages, yet its share in the number of students was absolutely crucial. The number of colleges was small in today's view, but this was true not only at the end of the monarchy and in the inter-war period, but to a large extent also in the communist regime, despite a significant increase in the number of students. The substantial increase in the number of universities - along with a further rapid increase in the number of students was brought about in the 1990s. In college education, therefore, there existed a relatively small number of independent schools until recently.

Legislation and practice, therefore, in terms of the minimum number of higher education institutions, operated in many different ways than in numerous secondary or even elementary schools. It did not have to be about making any general adjustments applicable to a large number of diverse cases, as is commonplace, but laws regulating ad hoc specific questions. The famous law of 19 February 1920 No. 135/1920 Sb., to the regulation of Prague universities - often referred to as Lex Mareš - only governing the relations between the Czech and German section of Charles University in Prague, did not mean absurdly detailed legal regulation. Due to the extraordinary share of Prague's university in the number of students, it provided a substantial part of higher education. The national problem has been extremely sensitive since the end of the monarchy, especially since the 1880s, so this absurd prescription has certain logic.

The low number of universities further deepens the practical differences between minorities depending on their abilities, concentration and political influence. Current approaches to the protection of minorities prevailing since World War II and developed at the end of the $20^{\text {th }}$ century emphasize individual rights. This also leads to overlooking the very varied number of minority groups, as seen in the work of a key international organization on minorities, which is the Council of Europe. It usually rejects the differences between large and small groups, even miniaturized, or minority differences that are officially recognized or recognized in some form. However, real life enforces such differences, as is often the case with language-related questions, that is, the possibility of using their own language before the authorities or in minority education. Ensuring such rights to the smallest groups would be challenging, sometimes without considerable expense almost impossible.

Minority colleges are even more extreme - perhaps even the most striking. With the small number of universities that existed in Czechoslovakia until the 1990s, it was only realistic to think about the most numerous minorities. Small groups such as Croats from South Moravia or Bulgarians are therefore completely out of this perspective, and even more numerous minorities, such as the Poles in region Těšínsko, have only a minimal chance to be considered. It was practically possible to discuss mainly in the case of the Germans, perhaps the Hungarians, or the Ruthenians as well with respect to their assumed autonomy (internationally and constitutionally guaranteed but not implemented). We cannot overlook 
the position of the officially second state-forming nation, the Slovaks, whose position was not so remote from that of minorities. The statistics are therefore key: according to the census in 1921, there were 6.8 million Czechs, less than two million Slovaks but 3.2 million Germans, who were much more than all other members of minorities together.

There may be a question of why not to address the minority problem by any compromise. Such may be special faculties, or at least minority departments, or a more tolerable solution to language use. For example, in Finland, universities were bilingual and teachers had to master both Finnish and Swedish. Such approaches, by the way, are relatively unrelated to the courageous attitude of inter-war Czechoslovakia, chanting its unique minority colleges. In the widespread Central European conditions the idea of bilingualism was irritating even more significant to the minority Germans. The real functioning of universities with minority faculties or even only departments would probably be rather problematic. In the official rejection of the second culture (Czech or German), as was common in Prague at the end of the monarchy, for example, when people would visit the second language theater on the sly, co-operation could hardly work. It is certainly not to be overlooked that fighting nationalism was common among students and many incidents occurred among them. Multi-national colleges would in practice be a risk, in other words, the seed of constant incidents that would disturb the public and could complicate the international status of the state, as shown, in particular, by the so-called insigniada in 1934.

The Germans in Czechoslovakia as the only minority had their own colleges as well, namely the Prague University and the Prague and Brno technological universities, with the number of their students higher than that corresponding to the German share of the population. ${ }^{9}$ Minority higher education in Europe was unique, which is often reminded by the supporters of the first Czechoslovakia. On the other hand, however, these schools had existed since the time of the monarchy, so it was rather about whether the new republic would decide - or could even say dare - to abolish or at least significantly reduce them. In view of the extraordinary number of minorities and the power of the mother states, it would be a risky move.

This strenuous move, however, was made by the new state - despite the original promises of, for example, President Masaryk to Hungarian universities in Slovakia, where in Prešov theology was taught, mining in Banská Bystrica and law in Košice until the end of Old Hungary (law university was also prepared in Prešpurk - since 1919 called Bratislava). In Slovakia, Comenius University in Bratislava was newly founded as a Czechoslovak university with Czech and Slovak teaching, but the importance of Czech teachers was dominant.

\section{Legal regulation of minority issues at higher education institutions in inter-war Czechoslovakia}

Regarding the interpretation of minority education and its legislation at the end of the monarchy and in inter-war Czechoslovakia, its relatively fragmented solution has already been explained. School legislation was contained in a number of legal regulations and the minority aspects, mainly the language of instruction, were to be found in individual provisions. 
A similar fragmentation related to the actual regulations of higher education institutions, which were contained in dozens of very diverse legal regulations. Most of them were adopted from the monarchy, with the main ones being Act No. 63/1873, on the organization of university offices, Act No. 68/1893, on legal and state studies and state examinations, and decree No. 370/1850 Sb., which promulgates general regulations on faculty studies at universities. These unclear regulations usually survived until the completely new concept brought about by Act No. 58/1950 Sb., on higher education institutions. ${ }^{10}$

An important element was the principle responding to the above-mentioned discontinuity and thus the uniqueness of universities, which stipulated that significant changes at universities (not just their establishment) had to be regulated by law. This was contained in Act No. 28/1922 Sb., on the establishment and provision of higher education institutions, which stipulated in sec. 1 "Establishing state schools or new faculties and departments at state universities; divide their faculties or their departments or close them; determine or change the seat of state or departmental colleges; to confer rights that belong to state universities, also in case of non-state universities it is only possible on the basis of a special law and within its limits." The Act contained only this provision, because sec. 2 in several words concerned the validity, efficiency and implementation. Such miniature legislation was quite common in the education system at that time.

The key standards for universities included the establishment of the second Czech university in Brno, which was promised by Vienna already during the monarchy, but was implemented in the republic at its very beginning on 28 January 1919 (Act No. 50/1919 Sb., on establishment of second Czech university). In June 1919, the creation of a university for Slovakia (Act No. 375/1919 Sb., on the establishment of the Czechoslovak State University in Bratislava) was approved. ${ }^{11}$ In fact, the content of the law was only sec. 1 "In Bratislava, in place of the former Hungarian university shall be established Czechoslovakian state university with these four faculties: legal, medical, scientific and philosophical. The lectures are either in Czech or Slovak language." The establishment of universities in Brno and Bratislava does not seem to be a minority issue, but there was a clear preference of the state nation. In Bratislava, it was a direct replacement for the Hungarian university.

Minority issues of course include, in particular, provisions on the language of examinations at universities (e.g. Government Decree No. 122/1919 Sb., No. 353/1919 Sb., No. 214/1921 $\mathrm{Sb}$.). Only a relatively small response among members of minorities in its approval was created by Act No. 79/1919 Sb. (on the service of teachers of higher education, dated 13 February 1919), although with its 23 paragraphs was one of the most extensive regulations on the matter. ${ }^{12}$ The worst political consequences followed from the famous law of 19 February 1920 No. 135/1920 Sb. of the University of Prague - often referred to as Lex Mareš, as will be explained below.

10 In detail see BUŠEK, Vratislav - KOBOSIL, Emanuel: Vysoké školy [Universities], in: Slovník veřejného práva československého [Dictionary of Czechoslovak public law], Brno 1948, 449-468.

11 Dějiny Univerzity Karlovy IV, 1918-1990 [The History of Charles University IV, 1918-1990], Prague $1998,23$.

12 lbidem, 24. 


\section{Development of Minority Issues at higher education institutions in inter-war Czechoslovakia}

Naturally, the situation at the minority universities, which were exclusively German, was crucial, with the dominant role played by the German university in Prague. Compared to the Czech university, however, the number of students was only half. An interesting issue was the share of various branches - law was formerly the most common field of study, yet medicine prevailed after 1918, which was undoubtedly influenced by the smaller chances of German lawyers to work in the state administration. ${ }^{13}$

The most important events of the Prague German University during the inter-war era were anti-Semitic outbursts. Traditionally, at the German University, the proportion of Jews among students was very high, a quarter to a third, but with the incarceration even in the democratic republic - the share declined rapidly in 1937 by a tenth. Great rebellion occurred in 1922 against the new Rector Samuel Steinherz, who assumed office on the principle of rotation of functions and seniority. According to the Austrian tradition, as a Jew he had to resign immediately, but he did not. It sparked a wild strike by German students who even had support from abroad and from German municipalities in the border regions. Similar movements against Jewish academics occurred in 1923. Sometimes anti-Jewish outrages were in agreement with Czech nationalists, like in November 1929, when students demonstrated for introducing of so-called numerus clausus $^{14}$ inhibiting the Jews. ${ }^{15}$

University teachers also played a important part in the policy of the German minority. In the 1930s, Professor of Legal History, Mariano San Nicolo (Rector 1933-1934), was a key supporter of nationalism and anti-Semitism. He was even offered leadership of the key organization Heimatsfront (which would later become the strongest party of the SdP), which he refused and recommended Konrad Henlein instead. On the other hand, the professors of the German University were also supporters of pro-republican activism, like Robert Mayr-Harting and Franz Spin, who even became ministers in the Czechoslovak government. ${ }^{16}$

One of the most extensive minority conflicts in interwar Czechoslovakia, in which the Czech and German nationalists were depicted as shameful, was the so-called insigniada which at the end of November 1934 grew into a major riot. It was rather a formal dispute over whether the successor to the traditional Charles University was a Czech or German university in Prague. By Act No. 135/1920 Sb. (the so-called Lex Mareš), the Czech University was declared by the nationalist Professor Mareš as the exclusive and rightful heir of Charles University. Due to this fact, the German university was obliged to hand over the traditional signs - so-called insignia. However they were not handed over to the Czechs,

\section{Ibidem, 184.}

14 Comparison in Europe see Alma Mater Antisemitica, Wien 2016.

15 WOLMAR, Wolfgang Wolfram von: Prag und das Reich, Dresden 1943, 487-495; Dějiny Univerzity Karlovy..., 185. 16 Dějiny Univerzity Karlovy..., 185-186. 
and discussions continued as to whether the German university is a successor of Charles, the prestigious oldest university in Central Europe. ${ }^{17}$

In 1933 Professor Domin took over the office of the Rector of Charles University and started making steps to obtain the insignia. He first enforced the registration of Karolina, where they were deposited, as the property of the Czech University in land registers. This development caused a number of increasingly sharp conflicts, supported by the press, which did not cease even after the new Rector joined. On 20 November 1934, the Minister of Education, the famous lawyer prof. Jan Krčmár decided on the implementation of sec. 5 of Act No. 135/1920 Sb. The German Rector's Office refused to issue the insignia and German students, who were predominantly nationalistic or Nazi oriented, occupied Karolinum to prevent the transfer, leading to a clash with Czech students. As a result, there were extensive riots and nationalist battles that were attended more by mobs than students and led to 180 people being injured. The insignia was eventually handed over amidst great celebrations, even though they used only copies in academic practice, and that's so until today because the originals got lost during the war. ${ }^{18}$

In 1937, the Republic sought to amend Act No. 79/1919 Sb. on the service of teachers of higher education. This triggered a furious resistance of the German nationalists, who referred to the plans - there were three suggestions - as attempts to restrict the selfgovernment of universities. ${ }^{19}$ There were also strongly nationalistic or Nazi publications highlighting the importance of universities, especially Prague, for the German nation. ${ }^{20}$ However, the amendment to the law was not enforced in inter-war Czechoslovakia.

With the end of the first Czechoslovak Republic, the tragic end of the minority universities in the Czech lands, especially the existence of the Czech and German universities in Prague, came about. During the Nazi occupation in November 1939 Czech universities were closed, and after the war the dissolution of German schools, including high schools, was enforced.

\section{Conclusion}

Minority and national issues are still very sensitive to this day and, in particular, in the first half of the twentieth century, they were among the key elements of politics. Their objective assessment, and understanding of the time period, is complicated by their diversity - they are mainly involved in international, constitutional, and administrative law. A particularly specific but significant problem is the position of minorities in universities and their efforts

17 KÁRNíK, Zdeněk: České země v éře První republiky (II.) [Czech lands in the era of the First Republic (II.)], Prague 2002, 269-280; in detail see PETRÁŠ, Menšiny..., 228.

18 In detail see PETRÁŠ, Menšiny..., 228-229; KURAL, 134-135. WOLMAR, 555-567; Dějiny Univerzity Karlovy..., 23.

19 WOLMAR, 572-574 - this extensive 611-page publication brings detailed factography, but is sadly renowned for its Nazi conception.

20 Rechtskampf der Sudetendeutschen Hochschulen, Brünn - Wien - Leipzig (1937). This publication goes back to ancient history - for example, an interpretation by Josef Pfitzner (55-67). 


\begin{tabular}{|c|c|c|}
\hline 36 & $\begin{array}{l}\text { ARTICIES } \\
\text { Jan KUKLÍK } \\
\text { René PETRÁš }\end{array}$ & $\begin{array}{l}\text { The legal status of minorities and universities } \\
\text { in inter-war Gzechoslovakia }\end{array}$ \\
\hline
\end{tabular}

to create specific institutions. A remarkable example is inter-war Czechoslovakia, where a unique system of minority colleges operated. However, this situation cannot be idealized, as it was more about the survival of the German (as opposed to the Hungarian) universities of the monarchy.

\section{References}

BURGER, Hannelore: Sprachenrecht und Sprachgerechtigkeit im österreichischen Unterrichtswesen 1867-1918, Wien 1995.

BUŠEK, Vratislav - KOBOSIL, Emanuel: Vysoké školy [Universities], in: Slovník veřejného práva československého [Dictionary of Czechoslovak public law], Brno 1948, 449-468.

Dějiny Univerzity Karlovy IV, 1918-1990 [The History of Charles University IV, 1918-1990], Prague 1998.

HORÁČEK, Cyril: Jazykové právo československé republiky [Language Law of the Czechoslovak Republic], Prague 1928.

KÁRNíK, Zdeněk: České země v ére První republiky (II.) [Czech lands in the era of the First Republic (II.)], Prague 2002.

KURAL, Václav: Konflikt místo společenství? [Conflict Instead of Community?], Prague 1993.

PEŠKA, Zdeněk: Československá ústava a zákony s ní souvislé II [The Czechoslovak Constitution and Related Laws II], Prague 1935.

PETRÁŠ, René: Národní otázka v českých zemích na sklonku monarchie [The national question in the Czech lands at the end of the monarchy], in: Vývoj české ústavnosti $\checkmark$ letech 1618-1918 [The development of Czech constitutionality in years 1618-1918], MALÝ, Karel - SOUKUP, Ladislav (eds.), Prague 2006, 694-740.

PETRÁŠ, René: Menšiny v meziválečném Československu [Minorities in inter-war Czechoslovakia], Prague 2009.

PETRÁŠ, René: Problémy právního postavení menšin [Problems of legal status of minorities], in: Aktuální problémy právního postavení menšin v České republice [Current problems of the legal status of minorities in the Czech Republic], PETRÁŠ, René (ed.), Prague 2010, 35.

Rechtskampf der Sudetendeutschen Hochschulen, Brünn - Wien - Leipzig (1937).

SOBOTA, Emil: Národnostní právo československé [National Law of Czechoslovakia], Brno 1927.

TRAPL, Miloš: České menšinové školství v letech 1918-1938 [Czech minority education in years 1918-1938], in: České národní aktivity $v$ pohraničních oblastech první Československé republiky [Czech National Activities in the Borderlands of the First Czechoslovak Republic], Olomouc - Opava 2003, 109-117.

WOLMAR, Wolfgang Wolfram von: Prag und das Reich, Dresden 1943. 


\section{Authors}

prof. JUDr. Jan Kuklík, DrSc.

Ústav právních dějin, Právnická fakulta, Univerzita Karlova Institute of Legal History, Faculty of Law, Charles University nám. Curieových 901/7, 11640 Praha 1, Czech Republic kuklik@prf.cuni.cz

JUDr. PhDr. René Petráš, Ph.D.

Ústav právních dějin, Právnická fakulta, Univerzita Karlova Institute of Legal History, Faculty of Law, Charles University nám. Curieových 901/7, 11640 Praha 1, Czech Republic petras@prf.cuni.cz 